\title{
Long-interval monitoring reveals changes in the structure of a reptile community in a biogeographic transition zone
}

\author{
Diana Ferreira ${ }^{1,3}$, José C. Brito ${ }^{1,2}$, Xavier Santos ${ }^{1, *}$ \\ ${ }^{1}$ CIBIO/InBIO, Centro de Investigação em Biodiversidade e Recursos Genéticos da Universidade do Porto. \\ Rua Padre Armando Quintas, 4485-661 Vairão, Portugal. \\ 2 Departamento de Biologia, Faculdade de Ciências da Universidade do Porto. Rua do Campo Alegre, 4169- \\ 007 Porto, Portugal. \\ ${ }^{3}$ Current address: Department of Ecology and Evolution, Université de Lausanne. Biophore CH-1015 Lau- \\ sanne, Switzerland. \\ *Correspondence: E-mail: xsantossantiro@gmail.com
}

Received: 15 July 2017; returned for review: 14 November 2017; accepted 14 February 2018.

Transition zones between biogeographical regions are natural scenarios to examine responses to local disturbances between species with contrasting biogeographic affinities. We compared absolute abundances of reptile species between fieldwork surveys carried out in 1999-2001 and 20122014 along a $1.5 \mathrm{~km}$ linear transect at the Peneda-Gerês National Park (NW Portugal), an area located in the transition zone between Mediterranean and Atlantic biogeographical regions. During the 13-year period, wildfires in 2007 and 2009 burnt two adjacent areas located on the southern part of the study area. Based on Landsat imagery, land cover analysis demonstrated significant differences between both periods, with an increase of open areas caused by the wildfires. We performed 99 surveys and detected 1774 reptiles belonging to five lizard and six snake species. There were changes in the reptile assemblage: Lacerta schreiberi (Atlantic lizard) showed a decrease in relative abundance from the first period, Podarcis sp (wall lizards) showed an increase, and Psammodromus algirus (Mediterranean lizard) colonized the study site in the second period. This field-based monitoring study confirms niche modelling predictions that forecasted range contraction for some Atlantic reptiles and expansion for some Mediterranean reptiles. Our results emphasize the importance of long-term monitoring to understand the magnitude of disturbance impacts on (reptile) communities.

Key words: Climate warming, disturbance, population decline, reptile communities, wildfire.

The most important threat to terrestrial biodiversity is land-use change including habitat degradation and destruction (SALA et al., 2000). In the Mediterranean basin, fire is among the most important natural disturbances (KEELEy et al., 2012). Mediterranean landscapes are, therefore, dominated by fire-prone ecosystems with vegetation resulting from a long evolutionary associa- tion with fire (Pausas \& Keeley, 2009). In Portugal, wildfires are recognized as key disturbance agents both at small (withinhabitat) and large (ecosystems/landscapes) scales (Moreira et al., 2001).

Wildfires alter the structure of vegetation, which in turn immediately alters the availability of suitable habitats (SARÀ et al., 2006; Haslem et al., 2011) by, for example, 
changing the thermal conditions of the microhabitat (e.g. Webb et al., 2005), or producing shifts on key resources such as food availability (e.g. PAstro et al., 2013). Vegetation succession has been indicated as the major cause of changes in associated animal communities by means of changes in vegetation composition and structure (e.g. LetNic et al., 2004; SARÀ et al., 2006; BRotons et al., 2008). Along the post-fire ecological succession, different species often peak in abundance at different stages, and then decline as the plant succession proceeds beyond their optimal habitat conditions, due to changes in the availability of resources (Nimmo et al., 2012; VALENTiNe et al., 2012, Sмiтh et al., 2013). Such (immediate) alterations, combined with increased wildfire frequency, demand accurate quantification of wildfire effects on community dynamics, and on the different succession patterns after fires for management of natural resources (KRAWCHUK et al., 2009; DoRnelas, 2010).

Biogeographic crossroads are areas that accumulate exceptional species and habitat diversity across many taxonomic groups (SPECtor, 2002). These areas offer the opportunity to monitor species and habitats of different biogeographical origins, and to track their responses to fire (FERreira et al., 2016a). Reptiles constitute a good candidate taxon to describe changes in species composition and abundance in long-interval field monitoring. Reptiles are ectotherms, and accordingly, they are sensitive to alterations in thermal habitat, which is mediated by changes in habitat structure, since temperature influences their basic physiological functions, such as locomotion, growth, and reproduction
(Huey, 1982). Moreover, most species have reduced dispersal abilities and relatively small home-range sizes, which turn them especially vulnerable to rapid habitat changes (Gibbons et al., 2000). These factors make them useful for correlating environmental factors with species richness distribution at the local scale. Unfortunately, long-term or long-interval monitoring programs of reptiles are scarce, and this fact constrains the detection of trends in population size or health (Giввons et al., 2000).

In 1999-2001, one of the authors conducted fieldwork surveys of a reptile community located in a crossroad between the Atlantic and the Mediterranean biogeographical regions, in the North-western Iberian Peninsula (EEA, 2012). We repeated these surveys in 2012-2014, which gave us the opportunity to compare relative abundances of reptile species between both periods. Between these two periods, the area was affected by two fires. The main goal of this study was to examine the existence of a link between reptile abundance changes in this long-interval monitoring and shifts in habitat structure mainly imposed by the wildfires. We hypothesize that reptiles will respond to habitat alterations produced by the fires in opposing ways according to their biogeographic affinity (Ferreira et al., 2016a). In this biogeographic crossroad, we expect that Mediterranean species may be favoured by the wider availability of hotter and drier areas, while Atlantic species may experience reductions resulting for decreased availability of covered and humid sites, as it has been reported in other sites within the Mediterranean basin (SANTOS \& CHEYLAN, 2013). 


\section{MAterials AND METHOdS}

\section{Study area}

The study was carried out at the Homem River valley $\left(41^{\circ} 48^{\prime} \mathrm{N}, 8^{\circ} 7^{\prime} \mathrm{W}\right.$; mean altitude $740 \mathrm{~m}$ ), a fully protected site located in the Peneda-Gerês National Park (PGNP), North-western Portugal (Fig. 1). The mean annual rainfall is $3200 \mathrm{~mm}$, ranging from $55 \mathrm{~mm}$ in July to $457 \mathrm{~mm}$ in January with more than 130 rainy days per year. Mean air temperature varies between $7.9^{\circ} \mathrm{C}$ in January to $20.3^{\circ} \mathrm{C}$ in July, which is translated into wet winters and hot summers (Godinho \& Machado, 1993). The study area lies in the transition between the Atlantic and Mediterranean biogeographical regions (EEA, 2012), thus it exhibits a mosaic between Atlantic and Mediterranean microclimates (ICN, 1995; ARAújo et al., 2006). This mosaic holds a great diversity of plants, invertebrates, and vertebrates due to the co-occurrence in the same geographical area of species from both Atlantic and Mediterranean regions, resulting in high species richness (SOARES \& BRITO, 2007). The vegetation in the study site is composed by deciduous oak-forests of Quercus robur and Q. pyrenaica interspersed with small trees (Arbutus unedo or Ilex aquifolium) and scrubland of low shrubs of heath (Erica sp., and Calluna vulgaris), gorse (Ulex sp.), and tall scrubs of brooms (Cytisus sp. and Genista sp.) (Serra \& CARVALHO, 1989).

\section{The reptile community}

The PGNP is one of the most important sites in terms of reptile species richness in Portugal (Loureiro et al., 2008). The reptile community at the PGNP includes 20 reptile

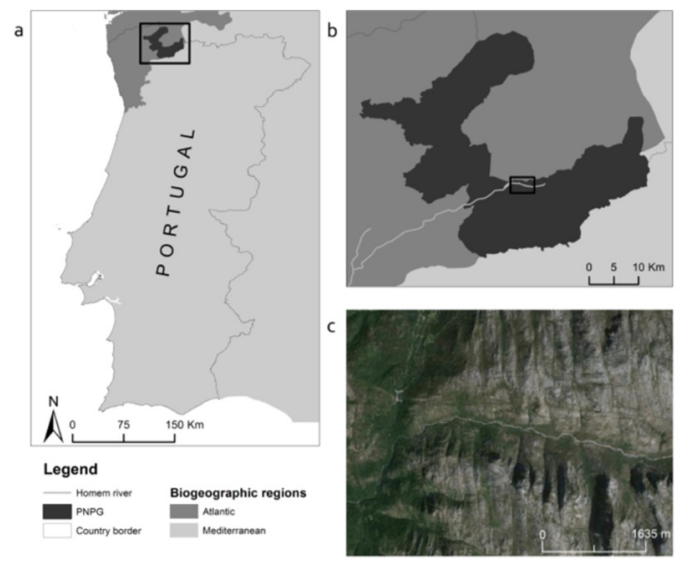

Figure 1: Location of the study area: (a) The Peneda-Gerês National Park (PGNP) is located in the extreme northern Portugal where two different biogeographic regions meet, the Atlantic and the Mediterranean (EEA, 2012); (b) Within PGNP, the Homem River valley is a fully protected site; (c) Satellite image of the study area from Google Earth in 2013.

species (SoAres et al., 2005) that reflect the transition character of the region, with a mixture of Atlantic and Mediterranean species (sensu Sillero et al., 2009) that can be found syntopically, according to the thermal and habitat-structure features (Ferreira et al., 2017). Eleven out of these 20 reptile species are found in the Homem River valley, which reflects the herpetological importance of this spot (SOARES \& BRIто, 2007).

\section{Field work procedures}

Reptiles were sampled in a $1.5 \mathrm{~km}$ linear transect at the southern riverside of the Homem River in two periods (1999-2001 and 2012-2014), and along the three seasons of reptile activity (spring, summer and autumn). Two wildfires, one in 2007 and another in 2009, burnt two adjacent areas located on the southern side of the 

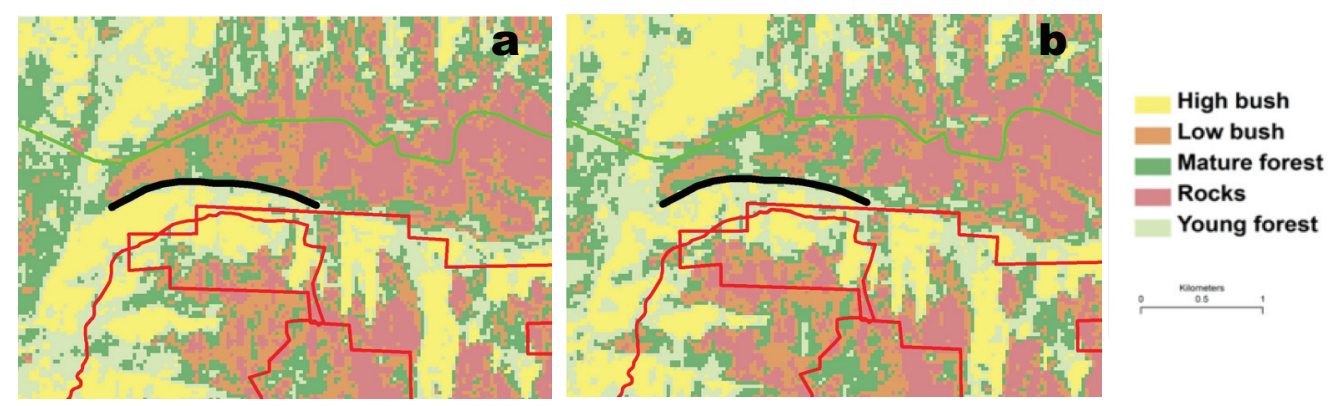

Figure 2: Land-cover maps resulting from the classification of Landsat 7 ETM+ satellite imagery of the study area from 1999 (a) and 2013 (b). Red lines indicate the outer edge boundary of fires, and the green line the limit of the National Park. The black line indicates the $1.5 \mathrm{~km}$ transect made at the Homem River valley. For a correct visualisation, consult the online version.

river, and reached the area where surveys were conducted (Fig. 2; GIS layers available on ICNF, Instituto de Conservação da Natureza e das Florestas; http:// www.icnf.pt/portal/florestas/dfci/inc/infogeo).

The fire polygons extracted from the ICNF dataset were not accurate in the wildfire limits. However, during the second sampling period, we saw evidences (burnt trunks) that the wildfire limits coincided with the transect along a significant part of the $1.5 \mathrm{~km}$ linear transect. To avoid statistical bias in comparisons of the abundances of species between periods, we used the same methodology and performed similar number of surveys (51 in 1999-2001 by J.C. BRITO, and 48 in 20122014 by D. Ferreira or X. Santos). During both periods, we balanced the number of surveys among the three seasons of reptile activity (spring, summer and autumn). Transect surveys were performed by one observer between 09:00 and 13:00 GMT in days with favourable (warm) climate conditions to maximize reptile sightings. In spring and autumn, the best period to see active reptiles was near noon, whereas in summer was early in the morning. We did not individually mark reptiles; thus, we cannot discard that some reptiles could be re-observed in weekly consecutive visits. However, visits were generally done at least one week apart from each other; thus allowing reptiles to move and relocate freely in their habitats, and reduce the probability of re-sampling the same individual (pseudo-replication). Consequently, we considered that two observations of the same individual at temporally distant visits were independent. Using visual encounter surveys, every reptile was identified (species, adult/juvenile, and sex if possible).

We acknowledge that inferring impacts of wildfire and climate shifts on reptile species based on a single $1.5 \mathrm{~km}$ transect may be risky, as there are no replicates to validate the observed pattern. We were constrained by the lack of old reptile monitoring surveys, especially in the Mediterranean-Atlantic transition zone. As far as 
we know, this is the first long-interval monitoring study that quantifies the degree of change in the composition of a reptile community located in a transition zone between bioregions.

\section{Habitat structure and local climate data}

Fire typically transforms the habitat and reduces the vegetation structure at the short term. For this reason, we selected five contrasting habitat classes according to the habitat structure and land cover gradient namely, mature forest, young forest, high scrubland, low scrubland, and rocky areas. Shifts in extent of these land cover classes between the surveyed periods were examined, with medium spatial resolution (30 m pixel) Landsat 7 ETM+ satellite imagery. The images selected covered an area of 1550 ha including both sides of the Homem River valley, and location of the transect in the centre of the image (Fig. 2). Images for the same month, July 1999 and July 2013, were selected to minimize problems of image incompatibility due to seasonal differences on phenology, and were downloaded from the USGS Earth Resources Observation and Science (EROS) Center, using the USGS Global Visualization Viewer (GloVis) online. Classification methods were used to produce comparable thematic maps of land-cover types (Nagendra et al., 2013). To discriminate land cover categories, we combined bands 4-5-3 assigned as red, green, and blue respectively, which are the most useful band combinations in Landsat for land cover discrimination (Scepan et al., 1999). All image processing was performed using ENVI 4.7 (Exelis VIS, 2010).

Burnt areas have a typical spectral sig- nature, especially if analysed by a multitemporal approach, because of the different vegetation coverage between pre-fire and post-fire conditions (Lentile et al., 2006). In order to compare habitat structure between pre-fire (1999) and post-fire (2013) conditions, we performed an image classification for both years. The unsupervised classification is commonly called "clustering", since it is based on the natural grouping of pixels in image data. We used the ISODATA clustering method (Tou \& González, 1974), which assembles pixels to a particular cluster based on its similarity of spectral signature (RICHARDS \& JIA, 2006). The bands from both years were classified into five spectral classes regarding its similarities in spectral signature. After the classification was completed, we applied our knowledge of the study area to label the spectral classes into the five informative land cover classes namely, mature forest, young forest, high scrubland, low scrubland, and rocky areas (see this procedure in Thapa \& Murayama, 2009).

Maps with the pixels assembled to the five habitat classes for 1999 and 2013 were exported to ArcGIS 10.2 (ESRI, 2013). GIS layers of the burnt areas in Portugal (ICNF, Instituto de Conservação da Natureza e das Florestas; http://www.icnf.pt/ portal/florestas/dfci/inc/info-geo) from 1999 to 2013 were intersected with our study area to identify the outer edge boundary of fires. The burnt area covered 510 ha (33\% of the study area) on the southern side of the Homem River whereas the area that remained unburnt occupied the remaining 1040 ha. Using GIS tools, we examined the extent of the five 
habitat classes (number of pixels assembled to each class) in the unburnt and burnt areas in 1999 and 2013.

We examined variation in climatic variables between both periods (see results as Supporting Materials Fig. S1). Thus, annual mean temperature and rainfall from the 1975-2014 period were retrieved from Ourense, distant $65 \mathrm{~km}$ from our study site (AEMET, 2015). This is the nearest meteorological station with this temporal data set available.

\section{Statistical analyses}

We constructed a contingency table with the number of pixels assigned to the five land cover classes for the 1999 and 2013 periods obtained with GIS tools. Variation in the number of pixels for each land cover class and between both periods was analysed with Pearson's chi-square test. We examined these temporal differences for the whole study area as well as for the burnt and unburnt areas separately.

Reptile abundances were examined by Generalized Linear Models (GLZs) with a Poisson distribution (due to the nature of the data, i.e. reptile counts), and with two grouping factors, Period (1999-2001 and 2012-2014) and Season, given that most reptiles in temperate regions may vary in abundance among seasons, according to their phenologies (McDiarmid et al., 2012). GLZ allows examining the effects of both factors, as well as their interactions. All analyses were performed with STATISTICA 10.0 (StatSoft Inc., 2010).

\section{Results}

\section{Habitat changes}

The extent of habitat classes did not vary in the 1999-2013 period $\left(\chi^{2}=2.24 ; \mathrm{df}=\right.$
4; $P=0.7$; Table 1 and Fig. 2), with only a low decrease of low bush class. However, when the burnt and unburnt areas were examined separately, results were opposing. The proportion of habitat classes varied in the burnt area between 1999-2013 ( $\chi^{2}$ $=11.59 ; \mathrm{df}=4 ; P=0.02)$, with a decrease of the high bush extent (probably the habitat class mostly burnt in 2007 and 2009), and an increase of low bush and rocky classes most likely as a consequence of the fire (Table 1 and Fig. 2). In the unburnt area, the extent of the habitat classes also experienced changes between 1999 and $2013\left(\chi^{2}=\right.$ 11.01 ; $\mathrm{df}=4 ; P=0.02)$; we detected an increase of young forest and high bush extent, and a decrease of low bush and rocky extent (Table 1 and Fig. 2), most likely linked to a natural vegetation growth in the area. We did not detect a significant trend in annual rainfall between both study periods (Supporting Material Fig. S1). Regarding temperature, we did not observe any trend during the 1999-2014 period; in contrast, mean annual temperature significantly increased around $1.5^{\circ} \mathrm{C}$ within the 1975-2014 period for which climatic data was available (Supporting Material Fig. S1).

\section{Reptile distribution and abundance changes}

During the total 99 surveys made at the Homem River valley, we detected 1774 reptiles belonging to six lizard and five snake species (Table 2). The most common taxon was the wall lizard Podarcis sp., represented at the study site by $P$. guadarramae lusitanica and P. bocagei. Abundances of both species were pooled due to the difficulties to identify juveniles in the field. In terms of species composition, the single 
Table 1: Temporal variation from 1999 to 2013 on the extent of five habitat types in the whole, burnt and unburnt areas at the Homem River valley according to the spectral information of each pixel (Landsat images from 1999 and 2013). The total number of pixels on each area is denoted in the first column. The pattern is expressed as the difference between both periods; less than $1 \%$ of variation is considered as "no change".

\begin{tabular}{|c|c|c|c|c|c|}
\hline & & 1999 (\%) & $2013(\%)$ & Difference & Pattern \\
\hline \multirow{5}{*}{$\begin{array}{c}\text { Total } \\
\text { Area } \\
\text { (15484500 pixels) }\end{array}$} & Mature forest & 20.79 & 20.31 & -0.48 & No change \\
\hline & Young forest & 20.74 & 21.56 & 0.82 & No change \\
\hline & High bush & 20.07 & 20.37 & 0.30 & No change \\
\hline & Low bush & 18.60 & 17.37 & -1.23 & Decrease \\
\hline & Rocks & 19.80 & 20.39 & 0.59 & No change \\
\hline \multirow{5}{*}{$\begin{array}{c}\text { Burnt } \\
\text { Area } \\
\text { (5093155 pixels) }\end{array}$} & Mature forest & 17.45 & 17.96 & 0.51 & No change \\
\hline & Young forest & 21.46 & 20.62 & -0.84 & No change \\
\hline & High bush & 28.66 & 23.60 & -5.07 & Decrease \\
\hline & Low bush & 17.48 & 18.62 & 1.14 & Increase \\
\hline & Rocks & 14.95 & 19.21 & 4.26 & Increase \\
\hline \multirow{5}{*}{$\begin{array}{c}\text { Unburnt } \\
\text { Area } \\
\text { (10391345 pixels) }\end{array}$} & Mature forest & 22.43 & 21.47 & -0.96 & No change \\
\hline & Young forest & 20.39 & 22.02 & 1.63 & Increase \\
\hline & High bush & 15.86 & 18.79 & 2.93 & Increase \\
\hline & Low bush & 19.15 & 16.75 & -2.39 & Decrease \\
\hline & Rocks & 22.18 & 20.97 & -1.21 & Decrease \\
\hline
\end{tabular}

difference between sampling periods was the presence of the lizard Psammodromus algirus in 2012-2014, which was not found during the 1999-2001 surveys.

GLZs detected seasonal differences in the total number of reptiles found per survey (more reptiles in autumn than in spring and summer; Table 2). There were seasonal differences in the absolute abundances of Natrix natrix (more abundant in spring), Timon lepidus (more abundant in summer), Lacerta schreiberi, Podarcis sp, and Vipera latastei (more abundant in autumn). The GLZs found inter-period differences in the Mediterranean in Podarcis sp. (more abundant in 2012-2014), and in the Atlantic L. schreiberi (more abundant in 1999-2001). Moreover, the number of species seen per transect in the 20122014 period was higher in comparison to the 1999-2001 period (average values 4.15 and 3.29, respectively; Table 2).

\section{Discussion}

Our long-interval monitoring study points to a change in the reptile community at a Mediterranean-Atlantic transition zone in terms ofspecies composition and 
FERREIRA ET AL.

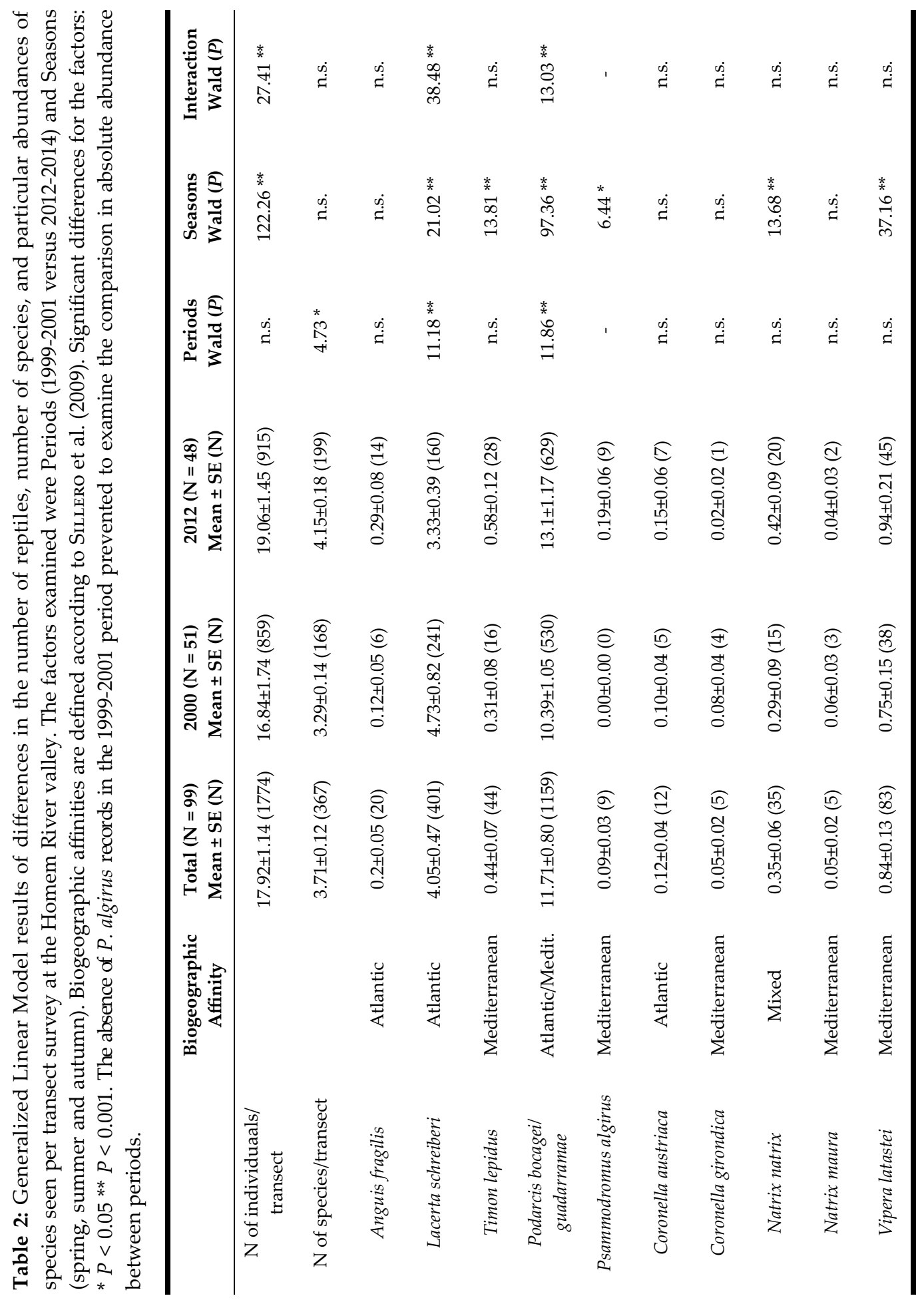


abundance from 1999 to 2014. We acknowledge that environmental (habitat) and reptile abundances were presented independently, and no empirical tests for the synergic effects were made.

While changes in reptile community structure occurred, the connection with habitat changes (being caused by wildfires, climate change, or even changes in detectability) is correlative. Moreover, we are aware that making inferences based on a single transect with no replicates may be dubious; this was motivated by the lack of old reptile surveys. At the Homem valley, the existence of old surveys and the occurrence of two wildfires made an excellent opportunity to reach the objective of this study. Despite the logistic limitations of this study, we are confident that our results showed changes in the reptile community that are congruent in some way with: 1) the modelling predictions for some reptile species found in the study area (e.g. Carvalho et al., 2010); 2) the species-specific microhabitat thermal preferences of reptile species (FERrEIRA et al., 2017); and 3) the biogeographic hypothesis that states the direction of change for some species according to their biogeographic affinity linked to fire disturbance (FERREIRA et al., 2016a). In our study, changes in the reptile community were limited to the decline of an Atlantic lizard ( $L$. schreiberi), and the increase of wall lizards of the genus Podarcis, while a Mediterranean lizard occurred for the first time in 2012 ( $P$. algirus).

We did not detect a significant trend in climatic variables during the 13-year interval (although an increase of temperature was observed in the 50-year period with climatic data available; Supplementary Materials Fig. 1). In contrast, the temporal variation in the habitat structure was conclusive. Between the two reptile surveys, we detected a trend towards more open landscapes due to the decreasing of areas with tall scrubland and increasing of rocky areas, that resulted from the 2007 and 2009 wildfires. There was an increase of young forest and high bush extent in the unburnt side, consequently with a decrease in low bush and rocky areas, which match the hypothesis of vegetation growth from 1999 to 2013. Changes in land cover type after wildfires matched our expectations, as fire altered the structure of vegetation and likely changed local environmental features important for reptiles (e.g. solar radiation, KAsischKe et al., 1995). As ectotherm species, reptiles are sensitive to thermal variation in the landscape (SCHREUDER \& Clusella-Trullas, 2016), and show strong responses to post-fire habitat changes (Driscoll et al., 2012; SAntos \& Cheylan, 2013; SAntos et al., 2016), both in terms of species distribution at large scale and relative abundances at small scales (e.g. BURY, 2004; Valentine \& SchwarzKopf, 2008; PAstro et al., 2013). We acknowledge that a reduction of vegetation structure could affect the detectability of reptiles, particularly lizards (higher detectability in open burnt habitats). However, the opposing responses of at least two lizards suggest no detectability effects.

We identified that responses of some species likely to the habitat shifts (FERREIRA et al., 2017) produced by the fires were also driven by their biogeographic affinities (Ferreira et al., 2016a); an Atlantic lizard declined (Lacerta schreiberi), while 
a Mediterranean lizard occurred for the first time in 2012 (Psammodromus algirus). Our results suggest that $P$. algirus has benefited from the increased availability of open areas with amplified solar radiation and dryness (SoARes et al., 2005). Due to its low water stress and high temperature selection (FERreira et al., 2016b), we think that this species colonized new habitats at the Homem River valley from the burnt areas at the northern part of the valley, which acted as corridor (Ferreira et al., 2017). Moreover, our study area is the northernmost limit of $P$. algirus distribution (Sillero et al., 2014), so it probably promotes a strong selection for the most opened and hotter microhabitats available. This result is in agreement with other works describing the colonization abilities of burnt sites by this lizard (SANTOS \& Poquet, 2010), including the PGNP (Ferreira et al., 2016a).

In the opposing way, habitat simplification might have negatively affected the abundance of the endemic L. schreiberi, given that wildfire alters its specific habitat requirements, i.e. well-established canopy and humidity (BRITo et al., 1998; FERREIRA et al., 2017). These effects could contribute to the contraction of its distribution area (Rödder \& Schulte, 2010; MorenoRueda et al., 2011). The endemic L. schreiberi has a restricted distribution range in the north-western part of Iberian Peninsula within the Atlantic climatic corridor, and several isolated populations in southern patches, where it shows strong preference for riparian habitats (BRITO et al., 1998). Given its narrow ecological niche breath and a restricted distribution, specially affected by climate change (CARvalHo et al., 2010), it is "close to qualifying for Vulnerable" (SÁ-Sousa et al., 2009). We suggest that this lizard species could be used as a key indicator of how Atlantic species are affected by wildfire occurrence in northwestern Iberian Peninsula. Long-term monitoring will be then useful to detect changes on its populations (BRITo et al., 1999; Carvalho et al., 2010).

Two Podarcis species occurring in the study area are characterised by different biogeographical affinities. However, the thermal physiology of wall lizards of the genus Podarcis is rather conserved across their phylogeny, and particularly these species have similar thermal physiologies (Ferreira et al., 2016b; Sannolo et al., 2018), and generally select rocky spots and open areas. Thus, the increased observation of Podarcis lizards along the transect between both sampling periods, would support the general hypothesis of changes (i.e. openness) in the habitat.

The observed trend of increasing temperature in the study area since 1975, will likely produce an increase in the fire risk (Moriondo et al., 2006), acerbated with the fact that burnt areas are spatially aggregated, and have a higher probability of being burnt again (SALvador et al., 2005). In the same park as the present study (PNPG), Ferreira et al. (2016a) showed that sites that burnt several times showed less complex assemblage of reptiles. If the hypothesis of an increasing frequency of fire holds, and since the reptile community maintains its species richness at Homem River valley by segregating at the microhabitat level (FERREIRA et al., 2017), continued alteration of habitats could be translated into a simpler community. 
Interestingly, the opposing responses of one Mediterranean and one Atlantic lizards mirrors the results observed at larger geographic scales, and with ecological niche modelling. Based on historical casual records in Spain, Moreno-Rueda et al. (2011) observed a long-term significant northward shift of the northernmost boundary of many reptile species from 1940 to 2005. They further detected a significant correlation between these shifts and increasing temperature (MorenoRuedA et al., 2011). Hence, as climate warms, both Atlantic and Mediterranean species tend to move northwards, however, the former are likely to experiment range contraction, while the latter will tend to expand its range (Sinervo et al., 2010). On the other side, Araújo et al. (2006) identified the Iberian Peninsula as a region where major species losses are projected to occur in 2050, associated with an increased aridity trend. Carvalho et al. (2010) predicted major losses in suitable climatic spaces for endemic species occupying north-western Iberia, and concluded that species with Atlantic affinities would be more affected by climate warming than species with Mediterranean affinities.

Modelling approaches acknowledged high variability in the projections of range shifts, and highlighted the necessity to conduct field observations to corroborate the predictions. Our field-based study supports some of these predictions: i) the occurrence of the Mediterranean P.algirus at the Homem River valley near the cooler northern range of this lizard as predicted by Araújo et al. (2006); and ii) the case of $L$. schreiberi and $P$. algirus in which the former decreased in abundance whereas the latter increased as predicted by CARvalho et al. (2010). Despite Carvalho et al. (2010) predictions have been projected for the 20202080 period, we were able to detect it in situ, perhaps because fires accelerated the effects of climate change on the distribution of species at a shorter-term.

Our study suggests that two fire events in a 13-year period produced alterations in a local reptile assemblage. More interestingly, we detected that these disturbances triggered specific and opposing responses according to the biogeographic affinity of some lizard species (Ferreira et al., 2016a). In the Iberian and other southern European peninsulas, prone to be affected by wildfires (Keeley et al., 2012), distinct biogeographical regions are arranged in a latitudinal gradient (RIvas-Martínez, 1987). These areas feature rapid turnover of species, and habitats leading to great levels of species richness. Such areas are natural laboratories to study and forecast how local disturbances and, possibly, global changes can affect the spatial distribution of biological diversity. We propose to continue the monitoring of this reptile community, as well as other communities in transition zones, in order to detect changes in species distribution and dynamics.

\section{Acknowledgement}

We want to thank Ana Serronha, João Campos and Marc Franch for their assistance on ENVI and GIS softwares, and Peneda-Gerês National Park staff for their logistic support and for providing us valuable information, especially Henrique Carvalho and Armando Loureiro. The British Herpetological Society provided DF a 
grant from the Grant Student Scheme to support fieldwork. JCB and XS are supported by Fundação para a Ciência e Tecnologia, FCT (IF/00459/2013 and SFRH BPD/73176/2010, respectively). Fieldwork in the 1999-2001 period was financed by Instituto da Conservação da Natureza e das Florestas (PNPG/ICNF) and Plano Operacional do Ambiente.

\section{REFERENCES}

AEMET. (2015). Agencia Estatal de Metereología. Available at http://www.aemet.es/es/ portada. Retrieved on 31 October 2016.

Araújo, M.B.; Thuiller, W. \& Pearson, R.G. (2006). Climate warming and the decline of amphibians and reptiles in Europe. Journal of Biogeography 33: 1712-1728.

Brito, J.C.; Godinho, R.; Luís, C.; Paulo, O.S. \& CRespo, E.G. (1999). Management strategies for conservation of the lizard Lacerta schreiberi in Portugal. Biological Conservation 89: 311-319.

Brito, J.C.; Paulo, O.S. \& Crespo, E.G. (1998). Distribution and habitats of Schreiber's green lizard (Lacerta schreiberi) in Portugal. Herpetological Journal 8: 187-194.

Brotons, L.; Herrando, S. \& Pons, P. (2008). Wildfire and the expansion of threatened farmland birds: the ortolan bunting Emberiza hortulana in Mediterranean landscapes. Journal of Applied Ecology 45: 1059-1066.

BURY, R.B. (2004). Wildfire, fuel reduction, and herpetofaunas across diverse landscape mosaics in Northwestern forests. Conservation Biology 18: 968-975.

Carvalho, S.B.; Brito, J.C.; Crespo, E.J. \& Possingham, H.P. (2010). From climate change predictions to actions - conserving vulnerable animal groups in hotspots at a regional scale. Global Change Biology 16: 3257-3270.

Dornelas, M. (2010). Disturbance and change in biodiversity. Philosophical Transactions of the Royal Society of London B Biological Sciences 365: 3719-3727.

Driscoll, D.A.; Smith, A.L.; Blight, S. \& MainDONALD, J. (2012). Reptile responses to fire and the risk of post-disturbance sampling bias. Biodiversity and Conservation 21: 1607 -1625 .

EEA. (2012). Biogeographical regions shapefile. European Environmental Agency. Available at http://www.eea.europa.eu/data-andmaps/data/biogeographical-regions-europe1. Retrieved on 31 October 2016.

ESRI. (2013). ArcGIS Desktop: Release 10.2. Environmental Systems Research Institute, Redlands, CA.

Exelis VIS. (2010). Exelis, Visual Information Solutions Envi 4.7. Exelis Vis, Boulder, Colorado.

Ferreira, D.; Mateus, C. \& Santos, X. (2016a). Responses of reptiles to fire in transition zones are mediated by bioregion affinity of species. Biodiversity and Conservation 25: 1543-1557.

Ferreira, C.; Santos, X. \& Carretero, M.A. (2016b). Does ecophysiology mediate reptile responses to fire regimes? Evidence from Iberian lizards. PeerJ 4: e2107.

Ferreira, D.; Žagar, A. \& SAntos, X. (2017). Uncovering the rules of (reptile) species coexistence in transition zones between bioregions. Salamandra 53: 193-200.

Gibbons, J.W.; SсотT, D.E.; Ryan, T.J.; Buhlmann, K.A.; Tuberville, T.D.; MetTs, B.S.; Greene, J.L.; Mills, T.; Leiden, Y.; PopPY, S. \& WinNe, C.T. (2000). The global decline of reptiles, déjà vu amphibians. Bioscience 50: 653-666.

Godinho, S.F. \& Machado, M.S. (1993). A precipitação na Região Hidrográfica do Norte. O Clima de Portugal, fasc XLIV. Instituto Nacional de Meteorologia e Geofísica, Lisboa.

Haslem, A.; Kelly, L.T.; Nimmo, D.G.; Watson, S.J.; Kenny, S.A.; Taylor, R.S.; Avitabile, S.C.; Calister, K.E.; Spence-Bailey, L.M.; Clarke, M.F. \& BennetT, A.F. (2011). Habi- 
tat or fuel? Implications of long-term, postfire dynamics for the development of key resources for fauna and fire. Journal of Applied Ecology 48: 247-256.

HueY, R.B. (1982). Temperature, physiology, and the ecology of reptiles, In C. Gans \& F.H. Pough (eds.) Biology of the Reptilia Vol. 12, Physiology (C). Academic Press, London, pp. 25-91.

ICN. (1995). Plano de Ordenamento do Parque Nacional da Peneda-Gerês. Relatório de Síntese Instituto da Conservação da Natureza e Parque Nacional da Peneda-Gerês, Braga.

Kasischke, E.S.; Christensen, N.L. \& Stocks, B.J. (1995). Fire, global warming, and the Carbon balance of boreal forests. Ecological Applications 5: 437-451.

Keeley, J.E.; Bond, W.J.; Bradstock, R.A.; Pausas, J.G. \& Rundel, P.W. (2012). Fire in Mediterranean climate ecosystems: ecology, evolution and management. Cambridge University Press, Cambridge.

KrawchuK, M.A.; Moritz, M.A.; Parisien, M.A.; Dorn, J.V. \& Hayhoe, K. (2009). Global pyrogeography: the current and future distribution of wildfire. PLoS ONE 4: e5102.

Lentile, L.B.; Holden, Z.A.; Sмith, A.M.S.; Falkowski, M.J.; Hudak, A.T.; Morgan, P.; Lewis, S.A.; Gessler, P.E. \& Benson, N.C. (2006). Remote sensing techniques to assess active fire characteristics and post-fire effects. International Journal of Wildland Fire 15: 319-345.

Letnic, M.; Dickman, C.R.; Tischler, M.K.; TAMAYo, B. \& BeH, C.-L. (2004). The response of small mammals and lizards to post-fire succession and rainfall in arid Australia. Journal of Arid Environments 59: 85-114.

Loureiro, A.; Ferrand De Almeida, N.; Carretero, M.A. \& Paulo, O.S. (2008). Atlas dos Anfíbios e Répteis de Portugal. Esfera do Caos Editores, Lisboa.

McDiarmid, R.W.; Foster, M.S.; Guyer, C.; Gibbons, J.W. \& Chernoff, N. (2012). Reptile Biodiversity: Standard Methods for Inventory and Monitoring. University of California Press.

Moreira, F.; Rego, F.C. \& Ferreira, P.G. (2001). Temporal (1958-1995) pattern of change in a cultural landscape of northwestern Portugal: implications for fire occurrence. Landscape Ecology 16: 557-567.

Moreno-Rueda, G.; Pleguezuelos, J.M.; PizarRo, M. \& Montori, A. (2011). Northward shifts of the distribution of Spanish reptiles in association with climate change. Conservation Biology 26: 278-283.

Moriondo, M.; Good, P.; Durão, R.; Bindi, M.; Giannakopoulos, C. \& Corte-Real, J. (2006). Potential impact of climate change on fire risk in the Mediterranean area. Climatic Research 31: 85-95.

Nagendra, H.; Lucas, R.; Honrado, J.P.; Jongman, R.H.G.; Tarantino, C.; Adamo, M. \& Mairota, P. (2013). Remote sensing for conservation monitoring: Assessing protected areas, habitat extent, habitat condition, species diversity, and threats. Ecological Indicators 33: 45-59.

Nimmo, D.G.; Kelly, L.T.; Spence-Bailey, L.M.; Watson, S.J.; Haslem, A.; White, J.G.; Clarke, M.F. \& Bennett, A.F. (2012). Predicting the century-long post-fire responses of reptiles. Global Ecology and Biogeography 21: 1062-1073.

Pastro, L.A.; Dickman, C.R. \& Letnic, M. (2013). Effects of wildfire, rainfall and region on desert lizard assemblages: the importance of multi-scale processes. Oecologia 173: 603-614.

Pausas, J.G. \& Keeley, J.E. (2009). A burning story: the role of fire in the history of life. BioScience 59: 593-601.

Richards, J.A. \& Jia, X. (2006). Remote Sensing Digital Image Analysis, 4th ed. SpringerVerlag, Heidelberg, pp. 193-238.

Rivas-Martínez, S. (1987). Nociones sobre fitosociologia, biogeografia y bioclimatología, In M. Peinda M. \& S. Rivas-Martínez (eds.) La Vegetación de España. Universidad de Alcalá de Henares, Madrid, pp. 19-45. 
Röpder, D. \& Schulte, U. (2010). Potential loss of genetic variability despite well established network of reserves: the case of the Iberian endemic lizard Lacerta schreiberi. Biodiversity and Conservation 19: 2651-2666.

Sala, O.E.; Chapin, III F.S.; Armesto, J.J.; Berlow, R.; Bloomfield, J.; Dirzo, R.; HuberSanwald, E.; Huenneke, L.F.; Jackson, R.B.; Kinzig, A.; Leemans, R.; Lodge, D.; Mooney, H.A.; Oesterheld, M.; Poff, N.L.; Sykes, M.T.; Walker, B.H.; Walker, M. \& Wall, D.H. (2000). Global biodiversity scenarios for the year 2100. Science 287: 1770-1774.

Salvador, R; Lloret, F.; Pons, X. \& Piñol, J. (2005). Does fire occurrence modify the probability of being burned again? A null hypothesis test from Mediterranean ecosystems in NE Spain. Ecological Modelling 188: 461-469.

Sannolo, M.; Barroso, F.M. \& Carretero, M.A. (2018). Physiological differences in preferred temperatures and evaporative water loss rates in two sympatric lacertid species. Zoology: https://doi.org/10.1016/j.zool.2017.12.003.

Santos, X.; Badiane, A. \& Matos, C. (2016). Contrasts in short- and long-term responses of Mediterranean reptile species to fire and habitat structure. Oecologia 180: 205-216.

Santos, X. \& Cheylan, M. (2013). Taxonomic and functional response of a Mediterranean reptile assemblage to a repeated fire regime. Biological Conservation 168: 90-98.

Santos, X. \& Poquet, J.M. (2010). Ecological succession and habitat attributes affect the postfire response of a Mediterranean reptile community. European Journal of Wildlife Research 56: 895-905.

Sarà, M.; Bellia, E. \& Milazzo, A. (2006). Fire disturbance disrupts co-occurrence patterns of terrestrial vertebrates in Mediterranean woodlands. Journal of Biogeography 33: 843852.

Sá-Sousa, P.; Marquez, R.; Pérez-Mellado, V. \& Martínez-Solano, I. (2009). Lacerta schreiberi. The IUCN Red List of Threatened
Species. Available at http:// www.iucnredlist.org/details/11113/0. Retrieved on 31 October 2016.

Scepan, J.; Menz, G. \& Hansen, M.C. (1999). The DISCover validation image interpretation process. Photogramm Engineering and Remote Sensing 65: 1075-1081.

Serra, M.G.L. \& Carvalho, M.L.S. (1989). A flora e a vegetação do Parque Nacional da Penede -Gerês: Contribuição para o plano de ordenamento desta Área protegida. Colecção Natureza e Paisagem nํ․ Serviço Nacional de Parques, Reservas e Conservação da Natureza, Lisboa.

Schreuder, E. \& Clusella-Trullas, S. (2016). Exotic trees modify the thermal landscape and food resources for lizard communities. Oecologia 182: 1213-1225.

Sillero, N.; Bonardi, A.; Corti, C.; Creemers, R.; Crochet, P.; Ficetola, G.F.; Kuzmin, S.; Lymberakis, P.; Pous, P.D.; Sindaco, R.; Speybroeck, J.; Toxopeus, B.; Vieites, D.R. \& Vences, M. (2014). Updated distribution and biogeography of amphibians and reptiles of Europe. Amphibia-Reptilia 35: 1-31.

Sillero, N.; Brito, J.C.; SKidmore, A. \& Toxopeus, A. (2009). Biogeographical patterns derived from remote sensing variables: the amphibians and reptiles of the Iberian Peninsula. Amphibia-Reptilia 30: 185-206.

Sinervo, B.; Méndez-de-la-Cruz, F.; Miles, D.B.; Heulin, B.; Bastiaans, E.; VillagránSanta Cruz, M.; Lara-Resendiz, R.; Martínez-Méndez, N.; Calderón-Espinosa, M.L.; Meza-Lázaro, R.N.; Gadsden, H.; Avila, LJ.; Morando, M.; De la Riva, I.J.; Victoriano Sepulveda, P.; Rocha, C.F.; Ibargüengoytía, N.; Aguilar Puntriano, C.; Massot, M.; Lepetz, V.; Oksanen, T.A.; Chapple, D.G.; Bauer, A.M.; Branch, W.R.; Clobert, J. \& Sites, J.W. Jr (2010). Erosion of lizard diversity by climate change and altered thermal niches. Science 328: 894-899.

Smith, A.L.; Bull, C.M. \& Driscoll, D.A. (2013). Sucessional specialization in a reptile commu- 
nity cautions against widespread planned burning and complete fire suppression. Journal of Applied Ecology 50: 1178-1186.

Soares, C.; Álvares, F.; Loureiro, A.; Sillero, N.; Arntzen, J.W. \& Brito, J.C. (2005). Atlas of the amphibians and reptiles of Peneda-Gerês National Park, Portugal. Herpetozoa 18: 155-170.

SoAres, C. \& Brito, J.C. (2007). Environmental correlates for species richness among amphibians and reptiles in a climate transition area. Biodiversity and Conservation 16: 1087-1102.

Spector, S. (2002). Biogeographic Crossroads as priority areas for biodiversity conservation. Conservation Biology 16: 1480-1487.

Statsoft Inc. (2010). STATISTICA 10.0. Statsoft Inc. W Tulsa, Oklahoma, USA.

Thapa, R.B. \& Murayama, Y. (2009). Urban mapping, accuracy, and image classification: a comparison of multiple approaches in Tsukuba city. Japan Applied Geography 29: 135-144.

Tou, J.T. \& González R.C. (1974). Pattern recognition principles. Addison-Wesley Pub. Co., NASA, Readinb, MA.

Valentine, L.E.; Reaveley, A.; Johnson, B.; Fisher, R. \& Wilson, B.A. (2012). Burning in banksia woodlands: how does the fire-free period influence reptile communities? PloS ONE 7: e34448.

Valentine, L.E. \& Schwarzkopf, L. (2008). Effects of weed-management burning on reptile assemblages in Australian tropical savannas. Conservation Biology 23: 103-113. Webi, J.K.; Shine, R. \& Pringle, R.M. (2005). Canopy removal restores habitat quality for an endangered snake in a fire suppressed landscape. Copeia 2005: 894-900. 